\title{
In situ Measurements of Nutrient and Oxygen Fluxes in a Coastal Marine Benthic Community*
}

\author{
Charles S. Hopkinson ${ }^{1}$ and Richard L. Wetzel ${ }^{2}$ \\ ${ }^{1}$ University of Georgia Marine Institute, Sapelo Island, Georgia 31327, USA \\ ${ }^{2}$ College of William and Mary, Virginia Institute of Marine Sciences, Gloucester Point, Virginia 23062, USA
}

\begin{abstract}
Benthic nutrient and oxygen fluxes were measured during summer in the nearshore zone of the Georgia Bight, USA. Ammonium, nitrite, nitrate and phosphate were released by the sediments to the overlying water, while dissolved organic nitrogen was taken up by sediments. Oxygen uptake was equivalent to $1.1 \mathrm{~g} \mathrm{Cm}^{-2} \mathrm{~d}^{-1}$. Based on other data available for this area the benthos accounted for the remineralization of approximately $55 \%$ of net primary production and $25 \%$ of total community (benthic and pelagic) metabolism. To balance a simple carbon budget for the nearshore region during summer an outside source of organic matter, most likely originating in adjacent estuaries, is required. The benthos supplied $16 \%$ of the $\mathrm{N}$ and $53 \%$ of the P required by phytoplankton. Pore water nutrient concentrations suggested substantial denitrification (estimated at $4.9 \mathrm{mg} \mathrm{Nm}^{-2} \mathrm{~d}$ by mass balance) in sediments which may have caused the low $\mathrm{N}$ : $\mathrm{P}$ benthic release ratios we observed. The results support the hypothesis that benthic processes in shallow marine areas control the availability of $\mathrm{N}$ and $\mathrm{P}$ for water column production.
\end{abstract}

\section{INTRODUCTION}

The exchange of biogenic elements between bottom sediments and overlying water has long been recognized as one of the principal factors regulating chemical and biological cycles in lakes (Mortimer, 1942). However, it has only been in recent years that such exchanges have been found to be important in some coastal marine systems (Davies, 1975; Nixon et al., 1976; Rowe et al., 1977; Smith et al., 1978). Much remains to clarify the factors regulating benthic exchange rates (Hargrave, 1973; Nixon, 1981), the importance of benthic fluxes relative to other nutrient sources (Haines, 1977; Woodwell et al., 1977; Kinsey, 1980, Nixon, 1980), recycling mechanisms (Pomeroy et al., 1965; Johannes, 1969; Carpenter and McCarthy, 1978; Harrison, 1978) Caperon et al., 1979) and processes regulating the composition of materials released from sediments (Seitzinger et al., 1980). In view of the importance of benthic exchanges suggested by studies completed thus far, it is important to continue to inves-

\footnotetext{
- This is a joint contribution from the University of Georgia Marine Institute, Sapelo Island, GA 31327 (Contribution No. 462) and Virginia Institute of Marine Sciences, Gloucester Point, VA 23062 (Contribution No. 1058)
}

tigate these processes so that our conception of nutrient exchanges in coastal systems is more fully understood and that the benthic component can be placed in proper perspective.

Studies of nutrient cycling on the southeastern continental shelf are few and have largely been inferred from descriptions of nutrient concentrations and primary production. Emphasis in early studies was placed on determining the sources of nutrients for the shelf system. Using estimates of inputs from rivers, rainfall, the Gulf Stream and nitrogen fixation, most available evidence suggests that 'new' forms of nitrogen are of minor importance in the nearshore region of the Georgia Bight. Up to $95 \%$ of the inorganic nitrogen uptake in the nearshore environment of the Georgia Bight has been estimated to be supported by local in situ recycling (Haines, 1975, 1976a, 1979; Haines and Dunstan, 1975; Dunstan and Atkinson, 1976). While this indirect information on regeneration is significant, it is equally important to measure recycling processes directly.

Organic material outwelled from adjacent estuaries is an undetermined but potentially important source of nutrients to the nearshore environment. With the exception of Haines' studies (1976b, 1977), most evidence for southeastern estuaries generally supports the concept of outwelling (Turner et al., 1979; Kinsey, 
1980; Kjerfve and McKellar, 1980). The quantity of nutrients released by remineralization of outwelled organic matter may be substantial and may appreciably enhance offshore primary productivity.

We report here the first in situ measurements of benthic metabolism and nutrient exchange across the sediment/water interface in the southeastern nearshore environment. This area is adjacent to one of the most productive and largest expanses of tidal marshes along the eastern seaboard of North America. Also reported are pore water nutrient profiles, potential denitrification rates and data indicating the potential importance to the nearshore continental shelf region of organic matter outwelled from adjacent estuaries.

\section{STUDY SITE}

The nearshore coastal system studied was the shallow (average depth less than $10 \mathrm{~m}$ ), landward portion of the continental shelf in the Georgia Bight, USA. The zone extends from the extensive wetlands and barrier islands to the turbidity fronts about 10 to $15 \mathrm{~km}$ off shore. Nearshore waters are directly influenced by the many barrier island tidal inlets which are spaced about $15 \mathrm{~km}$ apart along the coast (Blanton and Atkinson, 1978). The sea immediately adjacent to the coast is highly turbid from water ejected tidally from the salt marshes. Seaward of the turbidity plumes there is evidence that salinity and/or turbidity fronts stranded from preceding tidal cycles run roughly parallel to shore. Horizontal and vertical gradients such as these inhibit the exchange of material ejected from inlets in the offshore direction unless tidal or wind-induced currents override the gradient (Blanton and Atkinson, 1978). Due to the geometrical configuration of the Georgia Bight, wave energy is very low and tidal energy is high in this nearshore environment.

At the site chosen for the July study, mean water depth is $3.7 \mathrm{~m}$ and the mean tidal fluctuation is $2.1 \mathrm{~m}$. Sediments are $96 \%$ fine sand, $1.5 \%$ silt, $1.5 \%$ clay (by weight) and contain a modest amount of shell fragments. Faunal assemblages were not investigated in this study but have been described for the area by Smith (1973) and Leiper (1973). The water column is rarely stratified (Haines, 1979). Our study site was $3 \mathrm{~km}$ offshore Sapelo Island, Georgia (30⒉ $\left.46^{\prime \prime} \mathrm{N}: 81^{\circ} 11^{\prime} 59^{\prime \prime} \mathrm{W}\right)$.

\section{METHODS}

In situ measurements of benthic oxygen uptake and net fluxes of dissolved organic and inorganic nitrogen and phosphorus between the sediment and overlying water were made using 4 opaque, acrylic hemispheres (volume $=32 \mathrm{l}$; area $=0.2 \mathrm{~m}^{2}$ ). Experiments were conducted during morning hours on flooding tides. Salinity was $33 \mathrm{ppt}$, temperature $28^{\circ} \mathrm{C}$. Light profiles (Licor Model 185 Quanta Meter) taken at solar noon indicated that the euphotic zone (1\% light level) did not reach the bottom. SCUBA divers gently placed the domes by hand to minimize sediment disturbance and assure that a $6 \mathrm{~cm}$ vertical flange was fully inserted into the sediments. Initial water samples from inside and outside the domes were similar in composition and indicated no disturbance during placement. Dark bottles $(300 \mathrm{ml})$ were incubated in situ and contemporaneously to provide a correction for oxygen and nutrient changes due to the water-column plankton community. Dissolved oxygen (DO) was measured continuously with air-calibrated polarographic oxygen electrodes (Orbisphere). Measurements in dark bottles were taken at the beginning and end of the experiment. Stirrers incorporated in the oxygen probe bodies ensured that water contained in the domes was thoroughly and continuously mixed. Water samples (60 ml) for nutrient analysis were withdrawn by syringe hourly for $4 \mathrm{~h}$. Outside water was admitted through a small port during sample withdrawal to avoid interstitial water exchange. Analytical methods for nutrient analyses followed those described by Grasshoff (1976) for $\mathrm{NH}_{4}{ }^{+}, \mathrm{NO}_{3}{ }^{-}, \mathrm{NO}_{2}{ }^{-}, \mathrm{PO}_{4} \equiv$, dissolved organic nitrogen (DON) and dissolved organic phosphorus (DOP). $\mathrm{NH}_{4}{ }^{+}$was determined immediately in the field. Water for other nutrients was filtered (prerinsed Gelman A/E $1.0 \mu \mathrm{m}$ glass fiber) and frozen in the field and analyzed within a week in the laboratory. Benthic community respiration and net nutrient fluxes were calculated from changes in concentration over time after corrections were made for planktonic contributions (Pamatmat, 1971; Smith, 1973; Nixon et al., 1976; Smith et al., 1978; Rowe et al., 1977; Hopkinson et al., 1978). The method can be summarized as follows: (a) calculate for domes the rate of change of compound concentration, $\mathrm{mgl}^{-1} \mathrm{~h}^{-1}$; (b) subtract similar rate of change measured in dark bottles; (c) correct for water volume and bottom surface area of domes, $\mathrm{mg} \mathrm{m}^{-2} \mathrm{~h}^{-1}$; (d) extrapolate to $24 \mathrm{~h}, \mathrm{mg} \mathrm{m}^{-2} \mathrm{~d}^{-1}$.

Sediment and pore water nutrient profiles were analyzed from undisturbed cores collected with a Reineck box corer. Box cores $(12 \times 25 \times 25 \mathrm{~cm})$ were subcored twice with $3 \mathrm{~cm}$ diameter chrome tubing and quickly frozen $\left(-80^{\circ} \mathrm{C}\right)$. Subsections $(2.5 \mathrm{~cm}$ intervals $)$ from 1 core were analyzed for percent water, bulk density, organic carbon and total nitrogen. Organic carbon and nitrogen were determined on dried subsamples using Coleman $\mathrm{C}$ and $\mathrm{N}$ analyzers. The second frozen subcore was sectioned at $1 \mathrm{~cm}$ intervals. Alternate sections were placed in centrifuge tubes and 


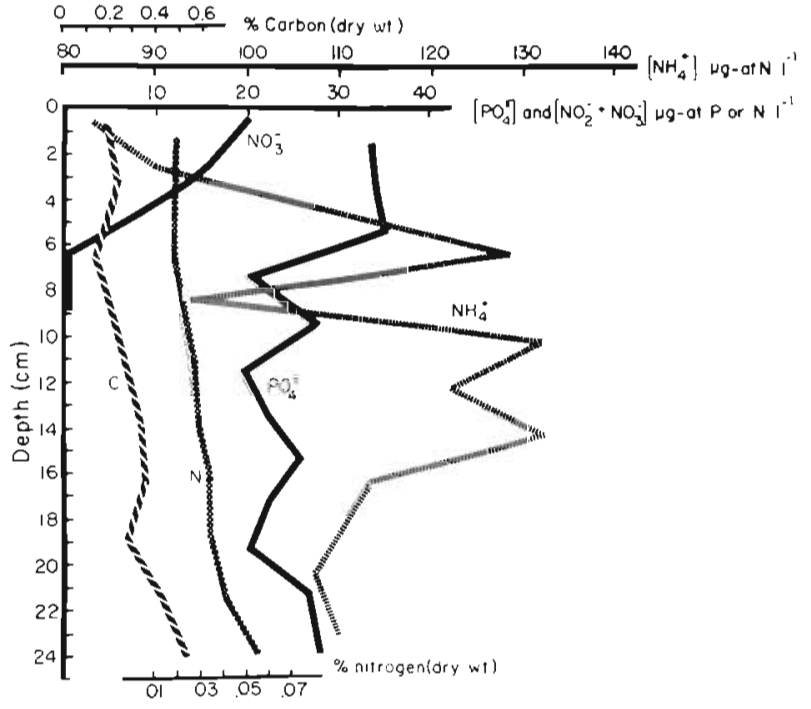

Fig. 1. Vertical profiles of measured concentrations of nitritenitrate, ammonium, phosphate, organic carbon and total nitrogen in nearshore sediments. Lines are means of 2 replicate analyses

diluted with $35 \mathrm{ml} 1 \mathrm{~N} \mathrm{NaCl}$ or $10 \mathrm{ml}$ P-free artificial seawater. Exchangeable $\mathrm{NH}_{4}{ }^{+}$was determined on $\mathrm{NaCl}$ treated sections after 5 min vortexing and $15 \mathrm{~min}$ centrifugation at $3000 \mathrm{rpm}$ (Black, 1965). Reactive phosphate $\left(\mathrm{PO}_{4}{ }^{\equiv}\right)$ and $\mathrm{NO}_{2}{ }^{-}+\mathrm{NO}_{3}{ }^{-}$were determined on the sections diluted with artificial seawater. Analysis was within 8 wk using techniques as described previously.

\section{RESULTS}

Dissolved nutrients, organic carbon and total nitrogen are plotted against depth in Fig. 1. Dissolved nutrient concentrations in the top $25 \mathrm{~cm}$ of the cores were always greater than concentrations in bottom waters. For example, ammonium values are about $110 \mu \mathrm{M}$ in the top $25 \mathrm{~cm}$ of sediment compared with $1.1 \mu \mathrm{M}$ in the overlying water. $\mathrm{NO}_{2}{ }^{-}$plus $\mathrm{NO}_{3}{ }^{-}$values ranged from 20 to $0 \mu \mathrm{M}$ in pore waters and were less than $1 \mu \mathrm{M}$ in bottom waters; $\mathrm{PO}_{4}=$ was $25 \mu \mathrm{M}$ in pore waters and $1.4 \mu \mathrm{M}$ in overlying water. The percent organic carbon and total nitrogen were low (comparable to deep sea sediments) and averaged about $0.3 \%$ and $0.03 \%$ of dry sediment wt, respectively.

The concentrations of the various compounds in the sediments exhibited several patterns of concentration with respect to depth. Organic carbon and total nitrogen slowly increased with depth; $\mathrm{NH}_{4}{ }^{+}$was variable but lowest near the surface; $\mathrm{PO}_{4}{ }^{\equiv}$ had a maximum at $6 \mathrm{~cm}$ and below that remained constant at a slightly lower level; nitrate was maximum at the surface and decreased continually to $6 \mathrm{~cm}$ below which it was undetectable.

Benthic oxygen consumption averaged 121 ( $\pm 10 \mathrm{~S}$.D.) $\mathrm{mg} \mathrm{O}_{2} \mathrm{~m}^{-2} \mathrm{~h}^{-1}$. The oxygen decrease was linear over time with the final concentration approaching $55 \%$ of the initial value. The variability between 4 replicate measurements was low (standard deviation $<10 \% \overline{\times}$ ).

The basic patterns of nutrient exchange were regeneration of ammonium, nitrite, nitrate, and phosphate, uptake of DON and no net exchange of DOP (Table 1). All exchanges were highly significant $(p<.01)$ with the exception of DON exchange rates. The time course of concentration change for $\mathrm{NH}_{4}{ }^{+}$and, to a lesser extent $\mathrm{NO}_{3}{ }^{-}$, was not linear but decreased during the initial hour or two, before increasing (Fig. 2). The initial decrease may have been caused by a bow wave advanced in front of the domes during placement. Quite possibly, overlying water was pushed into the sediment displacing interstitial water downward. If this hypothesis is correct, then the true nutrient exchange rate is calculated from the change in concentration measured during the last $3 \mathrm{~h}$ only. For ammonium, the exchange rate based on the final $3 \mathrm{~h}$ was $48 \%$ greater than the rate based on the entire $4 \mathrm{~h}$ observation (3960 vs $2680 \mu \mathrm{g}$-atNm ${ }^{-2} \mathrm{~d}^{-1}$ ).

Table 1. Nutrient exchange ( $\mu$ g-atom $\mathrm{m}^{-2} \mathrm{~d}^{-1}$ ) across the sediment/water interface and initial nutrient concentrations $\left(\mu \mathrm{g}\right.$-atom $\left.\mathrm{l}^{-1}\right)$ in the overlying water of the nearshore environment. Values given as release $(+)$ or uptake (-) of the nutrient by the sediment

\begin{tabular}{|c|c|c|c|c|}
\hline Constituent & $\begin{array}{l}\text { Initial } \\
\text { concen- } \\
\text { tration }\end{array}$ & $\begin{array}{c}\text { Mean } \\
\text { exchange }\end{array}$ & $\begin{array}{l}\text { Standard } \\
\text { error }\end{array}$ & $\begin{array}{c}\text { Error } \cdots \\
\text { mean }\end{array}$ \\
\hline $\mathrm{O}_{2}$ & $6.5^{\circ}$ & $-2.9 \cdots$ & \pm 0.12 & $\pm 5 \%$ \\
\hline $\mathrm{NH}_{4}^{+}$ & 1.1 & +3960 & \pm 510 & $\pm 13 \%$ \\
\hline $\mathrm{NO}_{2}^{-}$ & 0.11 & +120 & \pm 48 & $\pm 40 \%$ \\
\hline $\mathrm{NO}_{3}^{-}$ & 0.16 & +120 & \pm 22 & $\pm 18 \%$ \\
\hline DON & 24.3 & -80 & \pm 319 & $\pm 400 \%$ \\
\hline $\mathrm{PO}_{4}=$ & 1.4 & +880 & \pm 210 & $\pm 23 \%$ \\
\hline DOP & 0.0 & 0.0 & \pm 0 & $\pm 0 \%$ \\
\hline $\begin{array}{c}\Sigma \text { Inorganic } \\
\text { nitrogen }\end{array}$ & 1.26 & +4200 & \pm 580 & $\pm 14 \%$ \\
\hline$\Sigma N$ & 25.56 & +4120 & \pm 900 & $\pm 22 \%$ \\
\hline $\begin{array}{l}\Sigma \text { Inorganic } \\
\text { phosphorus }\end{array}$ & 1.4 & +880 & \pm 210 & $\pm 24 \%$ \\
\hline$\Sigma P$ & 1.4 & +880 & \pm 210 & $\pm 24 \%$ \\
\hline $\begin{array}{l}\sum \text { Inorganic } \mathrm{N} \text { : } \\
\Sigma \text { Inorganic } \mathrm{P}\end{array}$ & & $4.8: 1$ & & \\
\hline$\Sigma N: \Sigma P$ & & 4.7 & & \\
\hline \multicolumn{5}{|c|}{$\begin{array}{l}\text { - Units } \mathrm{mg} \mathrm{O}_{2} \mathrm{l}^{-1} \\
\cdots \text { Units } \mathrm{g} \mathrm{O}_{2} \mathrm{~m}^{-2} \mathrm{~d}^{-1} \\
\cdots \text { Expressed as the standard error of the exchange rate as a } \\
\text { percentage of the mean }\end{array}$} \\
\hline
\end{tabular}




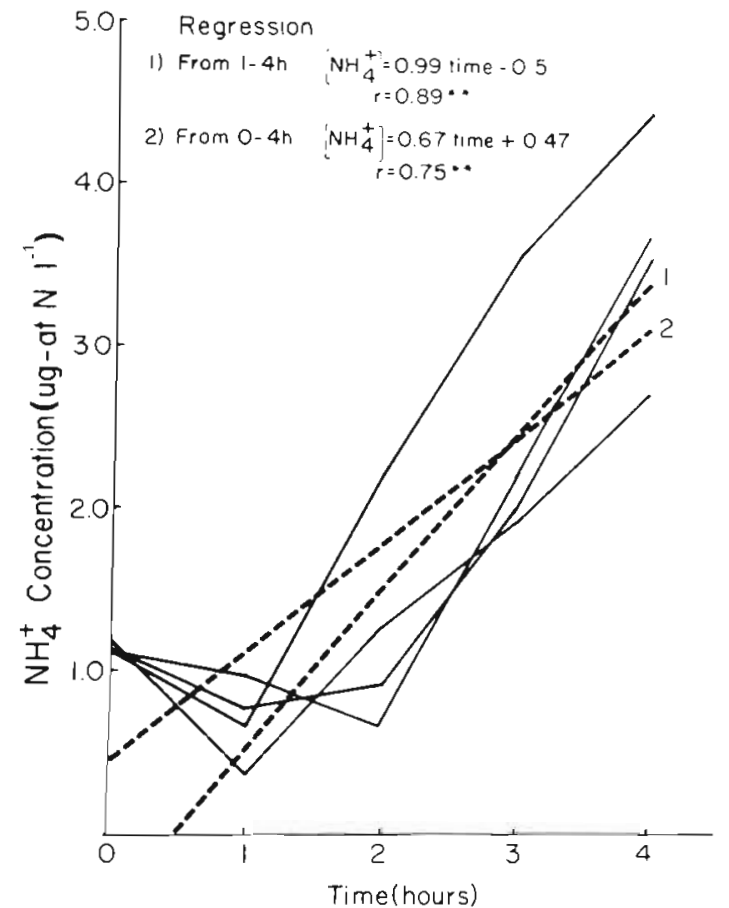

Fig. 2. Time course of change for the concentration of $\mathrm{NH}_{4}{ }^{+}$in water enclosed in hemispherical chambers. Points on each line represent means of 2 replicates

\section{DISCUSSION}

Benthic respiration was $2.9 \mathrm{~g} \mathrm{O}_{2} \mathrm{~m}^{-2} \mathrm{~d}^{-1}$ and is comparable to the highest previously reported values for estuarine and marine environments during summer (Kanwisher, 1962; Carey, 1967; Pamatmat, 1971; Hargrave, 1973; Smith and Teal, 1973; Rowe et al., 1975; Hartwig, 1976b; Nixon et al., 1976; Hopkinson et al., 1978; Smith, 1978; Boynton et al., 1980). Since water velocities in the domes were probably less than ambient, observed respiration rates were most likely conservative (Boynton et al., in press). This uptake rate of oxygen was very similar to that measured during summer by Smith (1973) in an organically richer zone of the nearshore Georgia Bight and by Hartwig (1976b) in a comparably carbon-impoverished nearshore region in southern California. Organic carbon and total nitrogen concentration in the sediments at the sampling site are low but typical of the Georgia nearshore region as a whole (Pinet and Frey, 1980). The possibility of tidal or diurnal metabolic rhythms was not examined.

Insights into the autotrophic heterotrophic state of the nearshore system are gained by comparing total community (benthic and pelagic) respiration with net primary production. For comparative purposes, the carbon equivalent of sediment oxygen uptake is useful and is calculated assuming an R. Q. = 1.0 (Pamatmat, 1971; Nixon et al., 1980). Phytoplankton ${ }^{14} \mathrm{C}$ primary productivity in the Georgia nearshore zone in summer was measured to be $2.0 \mathrm{~g} \mathrm{C} \mathrm{m}^{-2} \mathrm{~d}^{-1}$ (Thomas, 1966). Benthic respiration would account for the oxidation of $1.1 \mathrm{~g} \mathrm{C} \mathrm{m}^{-2} \mathrm{~d}^{-1}$ based on our dome data. This would indicate that an equivalent of $55 \%$ of water column net primary production was remineralized by the benthic community. Kinsey (1980) estimated total community respiration of $5.6 \mathrm{~g} \mathrm{C} \mathrm{m}^{-2} \mathrm{~d}^{-1}$ in a similar region of the nearshore zone off Sapelo Island, Georgia, using a free-water diumal oxygen technique which suggests that the benthos accounts for less than a quarter of total community metabolism.

Considering the metabolism of the benthos and the water column, our results indicate that a significant source of carbon in addition to in situ production is required to balance a simple carbon budget of the nearshore region for the summer season. The most likely organic matter input is material outwelled from the adjacent estuary. This indirect evidence supporting the outwelling hypothesis is partially supported by other studies (Kinsey, 1980; Kjerfve and McKellar, 1980). The observation is important because the belief that salt marshes export or outwell substantial amounts of organic matter has been recently questioned for several reasons that have been reviewed by Haines (1977) and Nixon (1980).

The flux of nutrients across the sediment water interface was overwhelmingly dominated by $\mathrm{NH}_{4}{ }^{+}$. A substantial flux of phosphate was also noted but was only a fifth of the $\mathrm{NH}_{4}{ }^{+}$flux. $\mathrm{NO}_{3}{ }^{-}$and $\mathrm{NO}_{2}{ }^{-}$were evolved from the sediments but fluxes were over an order of magnitude lower. The directions of the fluxes were as predicted from the concentration gradients across the sediment-water interface. The total flux of inorganic nitrogen was $4200 \mu \mathrm{g}$-at $\mathrm{N} \mathrm{m}^{-2} \mathrm{~d}^{-1}$ while the flux of phosphorus was $880 \mu \mathrm{g}$-at $\mathrm{P} \mathrm{m}^{-2} \mathrm{~d}^{-1}$. The total net flux of nitrogen, including the uptake of DON but excluding gases, was $4120 \mu \mathrm{g}$-at $\mathrm{N} \mathrm{m}^{-2} \mathrm{~d}^{-1}$ to the overlying waters. The flux rates of $\mathrm{N}$ are similar in magnitude and direction to those found by others while those for $P$ are among the highest previously reported for marine systems (Rowe et al., 1975, 1976; Hartwig, 1976a; Nixon et al., 1976; Aller, 1977; Boynton et al., 1980).

The importance of benthic nutrient regeneration for meeting uptake requirements of autotrophs can be approximated using published rates of primary production and a 106:16:1 C:N:P uptake stoichiometry (Redfield et al., 1963). For the nearshore region of the Georgia Bight, phytoplankton would require 26 and $1.7 \mathrm{mg}-$ at $\mathrm{N}$ and $\mathrm{P}^{-2} \mathrm{~d}^{-1}$, respectively. Using our daily benthic exchange rates of 4.2 and $0.9 \mathrm{mg}-$ at $N$ and $P$, the benthos supplied 16 and $53 \%$ of the daily phytoplankton requirement of $\mathrm{N}$ and $\mathrm{P}$ respectively. Thus 
the benthic regeneration of $\mathrm{N}$ and $\mathrm{P}$ provides a significant fraction of the daily phytoplankton requirement. This result is in agreement with the conclusion of and Davies (1975), Rowe et al. (1975, 1977), Hartwig (1976a) and Nixon et al. (1976).

An anomalously low ratio of nitrogen to phosphorus was released to the overlying water when compared to the basic Redfield nutrient model for the sea. Redfield et al. (1963) showed that the O-C-N-P ratio for the decomposition of organic matter in seawater averages $276: 106: 16: 1$; in the nearshore region of the Georgia Bight the $\mathrm{C} / \mathrm{N}$ ratio was $22: 1$ (versus $6.6: 1$ ), the $\mathrm{O} / \mathrm{N}$ ratio 40:1 (versus $17: 1$ ), and the $\mathrm{C} / \mathrm{P}$ ratio $101: 1$ (versus 106:1). Consequently, while phosphorus was released at an expected rate, nitrogen was not. This indicates why benthic nutrient regeneration supplied a much greater percentage of the autotrophic phosphorus requirement.

The C-N ratio in the sediment was the same as in the particulate organic matter of the overlying water (Haines and Dunstan, 1975). The similarity of the ratios indicates that, unless organisms selectively assimilate material with different proportions of $\mathrm{C}$ and $\mathrm{N}$, the food source of the benthic community also has a $\mathrm{C}-\mathrm{N}$ ratio of $10: 1$.

Based on our measured oxygen consumption rate, an $R Q$ of 1 and the measured food source $C: N$ ratio of $10: 1$, the expected exchange rate of nitrogen was $9.1 \mathrm{mg}$-at $\mathrm{m}^{2} \mathrm{~d}^{-1}$. This value is twice as high as the measured inorganic nitrogen regeneration of $4.2 \mathrm{mg}$ at $\mathrm{m}^{-2} \mathrm{~d}^{-1}$.

Two processes can lead to the anomalously low ratio of nitrogen to phosphorus release from sediments: preferential accumulation of $\mathrm{N}$ in sediments and denitrification. Pore water profiles of $\mathrm{NO}_{3}{ }^{-}$and $\mathrm{NH}_{4}{ }^{+}$and diagenetic models indicate the latter process to be responsible. The shape of the nitrate profile in the interstitial water (Fig. 1) is similar to that found by Vanderborght and Billen (1975) for sandy sediments of comparable organic matter content. Nitrification in the top layers of sediment would account for the high nitrate concentrations (Grundmanis and Murray, 1977). The decrease in nitrate concentration below the top few centimeters is accompanied by an increase in ammonium concentration with a maximum reached at approximately the same depth that $\mathrm{NO}_{3}{ }^{-}$becomes undetectable. These profiles indicate that nitrates are produced near the sediment surface and that denitrification occurs at deeper depths (Vanderborght and Billen, 1975; Grundmanis and Murray, 1977; McCaffrey et al., 1980). The constancy of the organic C to total $\mathrm{N}$ ratio $(10: 1)$ with depth in the sediment, implies that carbon and nitrogen are being remineralized at similar rates. Neither $\mathrm{C}$ nor $\mathrm{N}$ is being preferentially buried with depth.
Solution of simple C-N-P mass balance equations for $\mathrm{N}$ indicates that denitrification may amount to 4.9 $\mathrm{mg}$-at $\mathrm{Nm}^{-2} \mathrm{~d}^{-1}$ or $1.8 \mathrm{~g} \mathrm{Nm}^{-2} \mathrm{yr}^{-1}$. This flux exceeds the benthic release of $\mathrm{NH}_{4}{ }^{+}$and although it may appear quite large, it is of comparable magnitude to estimates reported for coastal bays and marshes (Valiela and Teal, 1979; Delaune and Patrick, 1980; Seitzinger et al., 1980). A flux of this magnitude is needed to account for the anomalously low ratio of nitrogen to phosphorus being released to overlying waters from the benthos. The denitrification sink for $\mathrm{N}$ must be balanced by 'new' inputs from adjacent rivers and/or estuaries, as nitrogen fixation is reported to be very low (Dunstan and Atkinson, 1976). Seitzinger et al. (1980) reported that denitrification represented a large sink for fixed nitrogen in Naragansett Bay also, being equivalent to almost half of the total input of $\mathrm{N}$ from sewage and rivers.

Nixon (1981) has shown that coastal systems in general appear to act as sinks for nitrogen. He hypothesized that denitrification in sediments leads to the characteristically low inorganic N/P ratios in the water column (1:1 in the nearshore region) and may be responsible for nitrogen being the major nutrient limiting primary production in coastal waters. These results support his hypothesis.

A logical progression of this study is to investigate on an annual basis the relative importance of benthic and pelagic processes in the overall carbon-nutrient dynamics of the nearshore environment. There is a great need to balance the carbon budget of coastal areas. The evidence for outwelling is conflicting at present and old paradigms still form the backbone of many arguments raised in favor of wetland conservation and preservation. A current major effort is the assessment of the importance of organic matter outwelled from the estuaries, not only as a source of carbon, but also as a potential source of nutrients for enhancing offshore primary production. A combination of measurements on internal recycling, including isotope ratio determinations of $\mathrm{NH}_{4}{ }^{+}$regeneration in the water column, and inputs from rivers should provide information regarding the role of the nearhore system as a component of the larger coastal marine ecosystem. Examination of the outwelling hypothesis from the receiving end rather than the source (mass budget in estuary) or conduit (Eulerian measurements in passes) is likely to be the most successful approach because the importance of catastrophic events such as storms or hurricanes on transport will be integrated.

Acknowledgements. This research was supported by the Georgia Sea Grant College Program and by the Sapelo Island Research Foundation, Inc. Thanks are extended to Bob 
Middleton, Steve Newell, Mary Robertson and Joe Schubauer for field and laboratory assistance, and to Lorene Gassert and Sarita Marland for manuscript preparation.

\section{LITERATURE CITED}

Aller, R. (1977). The influence of macrobenthos on chemical diagenesis of marine sediments. Ph. D. dissertation, Yale University, New Haven, Connecticut

Black, C. A. (ed.) (1965). Methods of soil analysis, Part. 2 , Chemical and microbiological properties, Am. Soc. Agron., Madison, Wisconsin

Blanton, J. O, Atkinson, L. P. (1978). Physical transfer processes between Georgia tidal inlets and nearshore waters. In: Wiley, M. L. (ed.) Estuarine interactions. Academic Press, New York, pp. 515-532

Boynton, W. R., Kemp, W. M., Osborne, C. (1980). Nutrient fluxes across the sediment-water interface in the turbid zone of a coastal plain estuary. In: Kennedy, V. (ed.) Estuarine perspectives. Academic Press, New York, pp. 93-110

Boynton, W. R., Kemp, W. M., Osborne, C., Kaumeyer, K., Jenkins, $M$. (in press). Influence of water circulation rate on in situ measurements of benthic community respiration. Estuar. coast. mar. Sci.

Caperon, J. D., Schell, D., Hirota, J., Laws, E. (1979). Ammonium excretion rates in Kaneohe Bay, Hawaii, measured by a ${ }^{15} \mathrm{~N}$ isotope dilution technique. Mar. Biol. 54 : $33-40$

Carey, A. G. (1967). Energetics of the benthos of Long IsIand Sound. I. Oxygen utilization of sediment. Bull. Bingham oceanogr Coll. 19: 136-144

Carpenter, E. J., McCarthy, J. J. (1978). Benthic nutrient regeneration and high rate of primary production in continental shelf waters. Nature, Lond. 274: 188-189

Davies, J. M. (1975). Energy flow through the benthos in a Scottish sea loch. Mar. Biol. 31: 353-362

Delaune, R. D., Patrick, W. H. (1980). Nitrogen and phosphorus cycling in a Gulf coast salt marsh. In: Kennedy, $V$. S. (ed.) Estuarine perspectives. Academic Press, New York, pp. 143-152

Dunstan, W. M., Atkinson, L. (1976). Sources of new nitrogen for the South Atlantic Bight. In: Wiley, M. (ed.) Estuarine processes, Vol. I. Academic Press, New York, pp. 69-78

Grasshoff, K. (1976) Methods of seawater analysis, Verlag Chemie, New York

Grundmanis, V., Murray, J. (1977). Nitrification and denitrification in marine sediments from Puget Sound. Limnol Oceanogr. 22: 804-813

Haines, E. B. (1975). Nutrient inputs to the coastal zone: the Georgia and South Carolina Shelf. In: Cronin, L. (ed.) Estuarine research, Vol. I. Academic Press, New York, pp. 303-324

Haines, E. B. (1976a) Nitrogen content and acidity of rain on the Georgia coast. Wat. Res. Bull. 12: 1223-1231

Haines, E. B. (1976b). Stable carbon isotope ratios in the biota, soils and tidal water of a Georgia salt marsh. Estuar. coast. mar Sci. 4: 609-616

Haines, E. B. (1977). The origins of detritus in Georgia salt marsh estuaries. Oikos 29: 254-260

Haines, E. B. (1979). Nitrogen pools in Georgia coastal waters. Estuaries 2 (1): $34-39$

Haines, E. B., Dunstan, W. M. (1975). The distribution and relation of particulate organic material and primary productivity in the Georgia Bight. Estuar. coast. mar. Sci. 3: $431-441$
Hargrave, B. T (1973). Coupling carbon flow through some pelagic and benthic communities. J. Fish. Res. Bd Can. 30 (9): $1317-1326$

Harrison, W. G. (1978). Experimental measurements of nitrogen remineralization in coastal waters. Limnol. Oceanogr. 23 (4): 684-694

Hartwig, E. O. (1976a). The impact of nitrogen and phosphorus release from a siliceous sediment on the overlying water. In: Wiley, M. (ed.) Estuarine processes, Vol. I. Academic Press, New York, pp. 103-117

Hartwig, E. O. (1976b). Nutrient cycling between the water column and a marine sediment. I. Organic carbon. Mar. Biol. 34: 285-295

Hopkinson, C. S., Day, J. W., Gael, B. T. (1978). Respiration studies in a Louisiana salt marsh. An. Centro Cienc. del Mar y Limnol. Unit. Nat. Auton. Mexico 5 (1): 225-238

Johannes, R. E. (1969). Nutrient regeneration in lakes and oceans. In: Droop, M. R., Wood, E. (eds.) Advances in the microbiology of the sea, Vol. I. Academic Press, New York, pp. 203-212

Kanwisher, J. W. (1962). Gas exchange of shallow marine sediments. Occ. Publs R. I. Grad. School Oceanog. 1: 13-19

Kinsey, D. W. (1980). The "outwelling" controversy. Abstract, Third Winter Meeting ASLO, Seattle, December 27-30, 1980

Kjerfve, B., McKellar, H. (1980). Time series measurements of estuarine material fluxes. In: Kennedy, V. (ed.) Estuarine perspectives. Academic Press, New York, pp. 341-358

Leiper, A. S. (1973). Seasonal change in the structure of three sublittoral marine benthic communities off Sapelo Island, Georgia. Ph.D. dissertation, University of Georgia, Athens, Georgia

McCaffrey, R. J., Myers, A., Davey, E., Morrison, G., Bender, M., Luedtke, N., Cullen, D., Froelich, P., Kinkhammer, G. (1980). Relation between pore water chemistry and benthic fluxes of nutrients and manganese in Narragansett Bay, R. I. Limnol. Oceanogr. 25 (1): 31-44

Mortimer, C. H. (1942). The exchange of dissolved substances between mud and water in lakes. J. Ecol. 29: 280--329

Nixon, S. (1980). Between coastal marshes and coastal waters - a review of twenty years of speculation and research on the role of salt marshes in estuarine productivity and water chemistry. In: Hamilton, P, Mācdonald, K. (eds.) Estuarine and wetlands processes. Plenum Press, New York, pp. 437-525

Nixon, S. (1981). Remineralization and nutrient cycling in coastal marine ecosystems. In: Neilson, B., Cronin, L. (eds.) Estuaries and nutrients. Humana Press, Clifton New Jersey, pp. 111-138

Nixon, S. W., Oviatt, C., Hale, S. (1976). Nitrogen regeneration and the metabolism of coastal marine bottom communities. In: Anderson, J., Macfadyen, A. (eds.) The role of terrestrial and aquatic organisms in decomposition processes. Blackwell Scientific, London, pp. 269-283

Nixon, S. W., Kelly, J, Furnas, B., Oviatt, C., Hale, S. (1980) Phosphorus regeneration and the metabolism of coastal marine bottom communities. In: Tenore, K., Coull, B. (eds.) Marine benthic dynamics. University South Carolina Press, Columbia, S.C., pp. 219-242

Pamatmat, M. M. (1971). Oxygen consumption of the seabed 6 . Seasonal cycle of chemical oxidation and respiration in Puget Sound. Int. Revue ges. Hydrobiol. 56: 769-793

Pinet, P. R., Frey, R. W. (1977). Organic carbon in surface sands seaward of Altamaha and Doboy Sounds, Ga. Geol. Am. Bull. 88: 1731-1739 
Pomeroy, L. R., Smith, E., Grant, C. (1965). The exchange of phosphate between estuarine water and sediments. Limnol. Oceanogr. 10: 167-172

Redfield, A. C., Ketchum, B., Richards, F. (1963). The influence of organisms on the compositon of seawater. In: Hill, M. (ed.) The sea, Vol. 2. Interscience, New York, pp. 26-77

Rowe, G. T., Clifford, C., Smith, K., Hamilton, P. (1975). Benthic nutrient regeneration and its coupling to primary productivity in coastal waters. Nature, Lond. 255: 215-217

Rowe, G. T., Smith, K. L., Clifford, C. H. (1976). Benthicpelagic coupling in the New York Bight. In: Gross, M. G. (ed.) ASLO Special Symposium, Vol. 2

Rowe, G. T., Clifford, C., Smith, K. (1977). Nutrient regeneration in sediments off Cap Blanc, Spanish Sahara. Deep Sea Res. 24: 57-63

Seitzinger, S., Nixon, S., Pilson, M., Burke, S. (1980). Denitrification and $\mathrm{N}_{2} \mathrm{O}$ production in near-shore marine sediments. Geochim. cosmochim. Acta 44: 1853-1860

Smith, K. L. (1973). Respiration of a sublittoral community. Ecology 54: 1065-1075

Smith, K. L. (1978). Benthic community respiration in the N. W. Atlantic Ocean: in situ measurements from $40-5200 \mathrm{~m}$. Mar. Biol. 47: 337-348
Smith, K. L., Teal, J. (1973). Deep-sea benthic community respiration: an in situ study at $1850 \mathrm{~m}$. Science, N. Y. 179: $282-283$

Smith, K. L., White, G., Laver, M., Haugsness, J. (1978). Nutrient exchange and oxygen consumption by deep-sea benthic communities: preliminary in situ measurements. Limnol. Oceanogr 23: 997-1005

Thomas, J. P. (1966). The influence of the Altamaha River on primary production beyond the mouth of the river. M. S. thesis, University of Georgia, Athens, Georgia

Turner, R. E., Woo, S., Jitts, H. (1979). Estuarine influences on a continental shelf plankton community. Science, N. Y. 206: 218-220

Valiela, I., Teal, J. M. (1979). The nitrogen budget of a salt marsh ecosystem. Nature, Lond. 280: 652-656

Vanderborght, J.-P., Billen, G. (1975). Vertical distribution of nitrate concentration in interstitial water of marine sediments with nitrification and denitrification. Limnol. Oceanogr. 20: 953-961

Woodwell, G. M., Whitney, D., Hall, C., Houghton, R. (1977). The Flax Pond ecosystem study: exchanges of carbon in water between a salt marsh and Long Island Sound. Limnol. Oceanogr. 22: 833-838

This paper was submitted to the editor; it was accepted for printing on July 27, 1982 